\section{Investigating Factors Influencing Consumer Adoption of Low-input Turfgrasses}

\author{
Chengyan Yue \\ Department of Horticultural Science and Department of Applied Economics, \\ University of Minnesota, Twin Cities, 1970 Folwell Avenue, St. Paul, MN \\ 55108
}

\author{
Manlin Cui \\ Department of Applied Economics, University of Minnesota, Twin Cities, \\ 1994 Bufford Avenue, St. Paul, MN 55108 \\ Eric Watkins \\ Department of Horticultural Science, University of Minnesota, Twin Cities, \\ 1970 Folwell Avenue, St. Paul, MN 55108
}

\section{Aaron Patton \\ Department of Horticulture and Landscape Architecture, Purdue University, 625 Agriculture Mall Drive, West Lafayette, IN 47907}

Additional index words. market segments, marketing strategies, sustainability

\begin{abstract}
Important financial savings, along with reductions in environmental impact, can be achieved by planting lawns with low-input turfgrass species. Drawing on data from an online survey, this article provides empirical evidence on the factors that influence consumers' willingness to adopt low-input turfgrasses. We group consumers into two segments: Willing Adopters and Reluctant Homeowners. Regardless of segment, consumers who regard maintenance requirements as more important were more willing to adopt low-input turfgrasses, whereas those who placed a higher value on appearance, were more unlikely to change to a low-input turfgrass, especially for Reluctant Homeowners. We categorized the barriers to adoption as follows: 1) Promotion, 2) Benefits and Accessibility, 3) Peer Effect, 4) Sample, and 5) Information. Our models predict that consumers' willingness to adopt low-input turfgrass can be significantly increased if the identified barriers are removed. Based on our study, suppliers/retailers should adopt heterogeneous and multiple marketing strategies, such as promoting through multiple channels, informing and advising the public on proper information, providing photos or exhibiting in-store samples, triggering communication between different types of consumers, and providing incentives and improving accessibility, to target different consumer groups.
\end{abstract}

Turfgrass is a major part of the urban landscape found on lawns, athletic fields, golf courses, cemeteries, parks, exposition and fairgrounds, and many other places (Jenkins, 2015; Milesi et al., 2005; Robbins, 2012). The pervasive feature of the home lawn can be explained by its economic and environmental benefits that few other landscapes can offer. Home lawns provide functional benefits to the environment such as soil carbon sequestration, soil erosion control, surface runoff

Received for publication 11 May 2021. Accepted for publication 28 June 2021.

Published online 25 August 2021.

This project is funded by U.S. Department of Agriculture, Specialty Crop Research Initiative, Grant Number 2017-51181-27222.

C.Y., E.W., and A.P. are Professors

M.C. is a $\mathrm{PhD}$ student.

C.Y. is the corresponding author. E-mail: yuechy@ umn.edu.

This is an open access article distributed under the CC BY-NC-ND license (https://creativecommons.org/licenses/by-nc-nd/4.0/). et al., 2006; Robbins and Birkenholtz, 2003; Soldat and Petrovic, 2008). Also, Maupin et al. (2014) pointed out that $\approx 40 \%$ to $75 \%$ of the total domestic water supply is used for landscape irrigation in the arid and semiarid regions of the United States. The increasing public demand for water resources for human consumption combined with the recent heat waves and prolonged droughts has raised public concerns about water scarcity and water quality (Mayer et al., 1999; U.S. Drought Monitor, 2020). In response, policymakers are increasingly looking to restrictions as a way to reduce water demand. In a number of states, restrictions on outdoor water use, fertilizers, and pesticides have been gradually imposed on lawn care (Lee and McCann, 2018; Milman and Polsky, 2016; U.S. Environmental Protection Agency, 2020).

In the northern half of the United States, kentucky bluegrass and perennial ryegrass are popular cool-season turfgrasses for lawns ( $\mathrm{Fu}$ et al., 2004; Fry and Huang, 2004; Huang and Fu, 2000; Qian et al., 1997; Su et al., 2008). However, their high-input characteristics can have a negative environmental impact, and present a challenge for long-term sustainability. As a result, researchers are exploring solutions to make the lawns more sustainable. Over the past few decades, turfgrass breeders have developed low-input turfgrass species that provide many of the same benefits as conventional turfgrass species while reducing the negative economic and environmental impacts due to their lower input requirements (Braun et al., 2020; Henry et al., 2005; Qian et al., 2010). Research has demonstrated that some lowinput turfgrass species, such as hard fescue (Festuca brevipila Tracey), and colonial bentgrass (Agrostis capillaris L.) perform well with reduced water, no fertilizer and pesticides, and reduced mowing (Braun et al., 2020; Hugie and Watkins, 2016; Watkins et al., 2011).

There are clear environmental and social benefits to increasing the use of low-input turfgrasses in home landscapes. However, to increase the market share and use of these grasses, it is crucial to understand the factors that influence consumers' adoption decisions. Previous studies provide some insights into these factors: a major theme of the literature in this area provides empirical support for consumer preference for low-turfgrass attributes and a second theme focuses on the barriers to the adoption of the low-input turfgrass species.

Yue et al. (2012) were the first to examine consumer preferences and willingness to pay for turfgrass attributes. They identified a strong consumer preference for reduced irrigation, mowing, and fertilizer requirements among Minnesota consumers. Hugie et al. (2012) conducted a conjoint analysis and found maintenance attributes of turfgrasses, specifically irrigation requirement, significantly affected consumer purchasing behavior. Yue et al. (2017a) indicated that both U.S. and Canadian consumers' preferences were largely affected by the ability of the turfgrasses to withstand foot traffic along with maintenance attributes of low mowing frequency, low water usage, and reduced fertilizer requirements; many 
consumers were willing to pay a high premium for turfgrass with low-input requirements. Ghimire et al. (2019) adopted a discrete-choice analysis and yielded similar conclusions finding that consumers in the South were willing to adopt water-conserving, climate-adapted landscape turfgrasses.

Few studies have explored the barriers that prevent consumers from adopting lowinput turfgrasses. As consumers' decisionmaking processes rest with their perceptions of products, information they have received about the product is critical to the choice (Heiner, 1985). In addition to price, revealed reluctance to adopt low-input grass could be because of a number of barriers. First, consumers cannot buy low-input turfgrasses if they are not aware these grasses exist. Barnes et al. (2018) conducted focus groups with land managers from the northern United States and found that the low-input turfgrasses were not as widely known as other types of turfgrass; this barrier is likely even greater for nonprofessionals. Second, it is likely that consumers do not have proper understanding of the benefits that low-input turfgrass species can provide. Yue et al. (2012) found that $62 \%$ of homeowners had no idea what type of grass they had in their lawn, and thus they were unlikely to understand the management requirements of the turfgrass. Third, consumers might have limited information sources to learn the benefits and thus would not make the adoption decision. Finally, consumers would not be able to purchase low-input turfgrasses when they are inaccessible. Identifying the barriers to adoption and strategies to reduce these barriers is very important for increasing consumers' willingness to adopt low-input turfgrasses.

This research builds on previous studies and aims to investigate the role of turfgrass attribute importance and adoption barriers in shaping turfgrass consumers' decision-making. Herein, we segment consumers into two groups, Willing Adopters and Reluctant Homeowners, and explore their preferences for important turfgrass attributes, investigate the barriers to the adoption of low-input turfgrasses, and identify the strategies to overcome these barriers for each segment.

\section{Methods}

Data collection. To investigate the factors that could influence consumers' willingness to adopt low-input turfgrasses, we first conducted a focus group discussion with a small number of participants. During the discussion, we asked questions about their current turfgrass species, turfgrass maintenance practices, their most important turfgrass attributes, and which barriers might prevent them from adopting low-input turfgrasses. Based on focus group input, we then designed a survey that aimed to collect data on the importance of the multiple turfgrass attributes to consumers, barriers to the adoption of lowinput turfgrasses, consumer willingness to switch to low-input turfgrasses, trustworthiness of various sources of lawn care information, and sociodemographic characteristics of participants. Qualtrics ${ }^{\mathrm{TM}}$, a professional survey company, provided the sample and randomly selected U.S. homeowners with home lawns to participate in the survey.

To measure consumer willingness to switch to low-input turfgrass, a primary focus of this study, we constructed a set of statements about participants' beliefs and attitudes toward the adoption of low-input turfgrasses. Participants were asked to rate the statements on a seven-point Likert scale ranging from "strongly disagree" to "strongly agree," with four being neither agree nor disagree with the statements. We calculated each participant's average rating for these statements and then segmented the participants into two groups based on participants' average rating: Willing Adopters and Reluctant Homeowners. The average rating of the Willing Adopters was higher than four, the neutral rating of being neither agree nor disagree with the statements, whereas the score of the Reluctant Homeowners was below or equal to four. Furthermore, instead of using the raw score, we standardized the willingness scores with mean 0 and standard deviation of 1 . Higher scores indicate higher levels of willingness to adopt.

We collected information on the importance of turfgrass attributes to consumers using a seven-point Likert scale ranging from "very unimportant" to "very important," corresponding to ratings one to seven. Participants were asked to rate the importance of a comprehensive set of 18 turfgrass attributes, such as color, mowing frequency, and ability to withstand foot traffic. Barriers to the adoption of low-input turfgrasses were identified through participants' degree of agreement to 18 potential adoption barrier statements in the questionnaire. We also collected participants' information sources for lawn care and how trustworthy they rated each source using a five-point Likert scale from "not trustworthy at all" to "extremely trustworthy." Last, we collected sociodemographic background information from all participants. Information included age, gender, educational attainment, region where their houses were located, whether they had children younger than 12 , whether they had pets that play on the home lawn, household size, income, how many years they expected to live in current residency, yard size, frequency of lawn maintenance, and their opinion toward low-input lawn maintenance.

Exploratory factor analysis. Exploratory factor analysis (EFA) is used to reveal the variability among higher number of observed and correlated variables in terms of a smaller number of latent variables or factors. We adopted the EFA technique to identify the major factors for the important turfgrass attributes and barriers to the adoption of low-input turfgrass. We first conducted the Kaiser-Meyer-Olkin (KMO) test and Bartlett test of sphericity to confirm that the EFA was appropriate. KMO tests whether the data are suited for factor analysis with a threshold of 0.7 . The Bartlett test of sphericity tests whether the correlation matrix is an identity matrix, indicating that factor analysis is inappropriate. KMO statistics for our data were all greater than 0.9 , and the significance levels of the Bartlett test of sphericity were 0.00 , suggesting the factor analysis was suitable.

There are several factor analysis methods. Fabrigar et al. (1999) suggested that if data are relatively normally distributed, maximum likelihood is the best choice. However, because a Likert scale is discrete and bounded, these data cannot be normally distributed; in this case, the principal factor analysis would be more appropriate. In addition, we chose the oblique rotation methods, as we usually expect some correlations among factors while orthogonal rotations produce factors that are uncorrelated. If the factors are truly uncorrelated, the orthogonal and oblique retention will yield nearly identical results. We used the screen test to decide how many factors to retain.

Empirical strategy. To explore the relationship between the importance of turfgrass attributes to the consumer and the barriers to the adoption and the consumer's willingness to adopt low-input turfgrasses, we estimate a linear model:

$$
Y_{i}=\alpha_{1}+\beta_{1} X_{i}+\beta_{2} Z_{i}+\varepsilon_{i},
$$

where the $Y_{i}$ is the standardized score of willingness to adopt low-input turfgrasses for participant $i ; X_{i}$ is a vector of factors stands for the importance of turfgrass attributes; $Z_{i}$ represents a vector of factors for the barriers to the adoption of low-input turfgrasses; and $\varepsilon_{i}$ is an error term. We calculated heteroskedasticity-robust standard errors in all regressions to improve efficiency.

\section{Results}

Summary statistics of survey participants. Table 1 presents descriptive statistics of participants' sociodemographic background information. In total, 2194 U.S. participants completed the survey. Most of the participants were from the South, followed by the Midwest, Northeast, and West. In our sample, the median age of the participants was 56 to 65 years old. More than $80 \%$ of participants were women. Most participants had completed high school. Approximately $18 \%$ had children younger than 12 years old and $58 \%$ had pets. The household size varied from one to more than eight. Most participants' annual income was less than $\$ 80,000$. More than half of participants expected to live in their current residency for more than 15 years and yard size varied from less than one-eighth of an acre to more than 1 acre. Most participants maintained their lawn weekly or biweekly; however, most of them thought "low-input" means lawn maintenance should be monthly or biweekly.

Importance of turfgrass attributes to consumers. The results of the importance of turfgrass attributes to consumers are presented in Table 2 . We found that participants highly valued the attributes related to the overall performance of the turfgrass and the maintenance requirements. The most important attributes to participants were weed resistance, followed by 
Table 1. Descriptive statistics of participants' sociodemographic characteristics of turfgrass adoption barrier survey $(\mathrm{N}=2194)$.

\begin{tabular}{|c|c|c|c|}
\hline & Frequency & Percent & Cumulative percentage \\
\hline \multicolumn{4}{|l|}{ Region } \\
\hline Northeast & 368 & 16.77 & 16.77 \\
\hline Midwest & 546 & 24.89 & 41.66 \\
\hline South & 931 & 42.43 & 84.09 \\
\hline West & 349 & 15.91 & 100.00 \\
\hline \multicolumn{4}{|l|}{ Age } \\
\hline $18-25$ & 46 & 2.10 & 2.10 \\
\hline $26-35$ & 188 & 8.57 & 10.67 \\
\hline $36-45$ & 268 & 12.22 & 22.88 \\
\hline $46-55$ & 371 & 16.91 & 39.79 \\
\hline $56-65$ & 617 & 28.12 & 67.91 \\
\hline $65+$ & 704 & 32.09 & 100.00 \\
\hline \multicolumn{4}{|l|}{ Gender } \\
\hline Female & 1766 & 80.49 & 80.49 \\
\hline Male & 428 & 19.51 & 100.00 \\
\hline \multicolumn{4}{|l|}{ Education } \\
\hline Some high school or less & 62 & 2.83 & 2.83 \\
\hline High school diploma & 379 & 17.27 & 20.10 \\
\hline Some college & 485 & 22.11 & 42.21 \\
\hline College diploma & 75 & 3.42 & 45.62 \\
\hline Some graduate school & 689 & 31.40 & 77.03 \\
\hline Graduate degree and above & 504 & 22.97 & 100.00 \\
\hline \multicolumn{4}{|l|}{ Children younger than $12^{\mathrm{z}}$} \\
\hline Yes & 389 & 17.73 & 17.73 \\
\hline No & 1805 & 82.27 & 100.00 \\
\hline \multicolumn{4}{|l|}{ Pets play on lawn ${ }^{y}$} \\
\hline Yes & 1277 & 58.20 & 58.20 \\
\hline No & 917 & 41.80 & 100.00 \\
\hline \multicolumn{4}{|l|}{ Household size } \\
\hline 1 & 444 & 20.24 & 20.24 \\
\hline 2 & 990 & 45.12 & 65.36 \\
\hline 3 & 327 & 14.90 & 80.26 \\
\hline 4 & 254 & 11.58 & 91.84 \\
\hline 5 & 108 & 4.92 & 96.76 \\
\hline 6 & 42 & 1.91 & 98.68 \\
\hline 7 & 17 & 0.77 & 99.45 \\
\hline $8+$ & 12 & 0.55 & 100.00 \\
\hline \multicolumn{4}{|l|}{ Household income } \\
\hline$\$ 15,000$ or less & 152 & 6.93 & 6.93 \\
\hline$\$ 15,001-\$ 25,000$ & 248 & 11.30 & 18.23 \\
\hline$\$ 25,001-\$ 35,000$ & 265 & 12.08 & 30.31 \\
\hline$\$ 35,001-\$ 50,000$ & 397 & 18.09 & 48.40 \\
\hline$\$ 50,001-\$ 65,000$ & 327 & 14.90 & 63.31 \\
\hline$\$ 65,001-\$ 80,000$ & 257 & 11.71 & 75.02 \\
\hline$\$ 80,001-\$ 100,000$ & 226 & 10.30 & 85.32 \\
\hline$\$ 100,001-\$ 150,000$ & 36 & 1.64 & 86.96 \\
\hline$\$ 150,001-\$ 200,000$ & 223 & 10.16 & 97.13 \\
\hline$\$ 200,001$ and over & 63 & 2.87 & 100.00 \\
\hline \multicolumn{4}{|l|}{ Expected years lives in current residency } \\
\hline $1-3$ & 316 & 14.40 & 14.40 \\
\hline $4-6$ & 276 & 12.58 & 26.98 \\
\hline $7-9$ & 145 & 6.61 & 33.59 \\
\hline $10-12$ & 292 & 13.31 & 46.90 \\
\hline $13-15$ & 105 & 4.79 & 51.69 \\
\hline $15+$ & 1060 & 48.31 & 100.00 \\
\hline \multicolumn{4}{|l|}{ Yard size } \\
\hline Less than $1 / 8$ acre & 420 & 19.14 & 19.14 \\
\hline City lot (1/8 acre) & 446 & 20.33 & 39.47 \\
\hline $1 / 4$ acre & 477 & 21.74 & 61.21 \\
\hline $1 / 2$ acre & 319 & 14.54 & 75.75 \\
\hline 1 acre & 223 & 10.16 & 85.92 \\
\hline More than 1 acre & 309 & 14.08 & 100.00 \\
\hline \multicolumn{4}{|l|}{ Frequency maintain your lawn } \\
\hline Does not maintain lawn by themselves & 481 & 21.92 & 21.92 \\
\hline Less frequency than every 3 months & 140 & 6.38 & 28.30 \\
\hline Every 3 months & 51 & 2.32 & 30.63 \\
\hline Every 2 months & 44 & 2.01 & 32.63 \\
\hline Monthly & 162 & 7.38 & 40.02 \\
\hline Biweekly & 470 & 21.42 & 61.44 \\
\hline Weekly & 735 & 33.50 & 94.94 \\
\hline More often than weekly & 111 & 5.06 & 100.00 \\
\hline
\end{tabular}

(Continued on next page) growing well in both sun and shade, price, disease tolerance, water requirements, appearance, and mowing frequency. We then used EFA to reduce the 18 turfgrass attributes to three latent factors: 1) Performance Attributes, 2) Maintenance Attributes, and 3) Appearance Attributes. We present the factor loadings that are greater than 0.45 .

The Performance factor is composed of nine items (origin, germination speed, ability to withstand foot traffic, winter tolerance, disease tolerance, grow well in both sun and shade areas, weed resistance, environmentally friendly, and seed shelf life) and explains $79 \%$ of the variance with factor loadings ranging from 0.54 to 0.69 . The Maintenance factor includes four items (mowing frequency requirement, water requirement, fertilizer requirement, and pesticide requirement) and accounts for $7 \%$ of the variance. The Appearance factor consists of four items (color, density, height of cut, and appearance) and explains $6 \%$ of the variance. We then calculated scores for each of the three latent factors; a higher score indicates a higher level of importance for the corresponding attribute.

Barriers to the adoption of low-input turfgrasses. We reduced the 18 measurements of barriers to the adoption of low-input turfgrass to five factors (Table 3): 1) Promotion, which accounts for $75 \%$ of variance, is the barrier due to the lack of stores/traditional media/ social media/government agencies' promotion or advertisement of low-input turfgrass; 2) Benefits and Accessibility, which explains $11 \%$ of the variance, is the barrier in which people do not know about potential monetary savings, lack monetary incentives, do not receive free samples, are not provided a lower price, or do not have access to the low-input turfgrasses; 3) Peer Effect, which delineates $5 \%$ of the variance, and represents the barrier that neighbors/public lawns/other households are not using low-input turfgrasses; 4) Sample, which represents $4 \%$ of the variance, and comprises the barrier of not seeing a sample in stores or an existing low-input turfgrass yard; and 5) Information, which accounts for 3\% of the variance, and measures the barrier of not knowing the positive environment effects of low-input turfgrasses and not having education programs informing them of how to maintain low-input turfgrasses. Similarly, we calculated scores for each factor. A higher score implies participants think a given factor is a more influential barrier.

Consumers' willingness to adopt low-input turfgrass. Table 4 presents the whole sample's average ratings on a set of statements measuring participants' willingness to adopt low-input turfgrasses. In general, participants in our study were willing to switch to low-input turfgrasses, and they were more inclined to do it gradually (i.e., increase the amount of low-input species throughout overseeding year after year rather than a complete lawn renovation, row 1-3). They believed low-input turfgrasses have more advantages and can save money (row 5-6). They also demonstrated widespread support for converting lawns to low-input turfgrasses (row 7-8). Moreover, they believed that 


\begin{tabular}{lrrr}
\hline & Frequency & Percent & Cumulative percentage \\
\hline Opinion on low-input maintenance standard & & & \\
Weekly or more frequency & 162 & 7.38 & 7.38 \\
Biweekly & 701 & 31.95 & 39.33 \\
Monthly & 793 & 36.14 & 75.48 \\
Every 2 months & 199 & 9.07 & 84.55 \\
Every 3 months & 143 & 6.52 & 91.07 \\
Every 4 months & 41 & 1.87 & 92.94 \\
Every 4 months & 24 & 1.09 & 94.03 \\
Every 5 months & 131 & 5.97 & 100.00 \\
\hline
\end{tabular}

${ }^{\mathrm{z}}$ Participants have one or more children younger than 12 years old in the household.

${ }^{\mathrm{y}}$ Participants have pets play on the lawn.

Table 2. Exploratory factor analysis for consumer preferences for turfgrass attributes based on turfgrass adoption barrier survey $(\mathrm{N}=2194){ }^{\mathrm{z}}$

\begin{tabular}{|c|c|c|c|c|c|}
\hline Attributes & Mean & SD & $\begin{array}{l}\text { Factor 1: } \\
\text { Performance }\end{array}$ & $\begin{array}{c}\text { Factor 2: } \\
\text { Maintenance }\end{array}$ & $\begin{array}{l}\text { Factor 3: } \\
\text { Appearance }\end{array}$ \\
\hline Color (e.g., dark green vs. light green) & 5.13 & 1.63 & & & 0.75 \\
\hline Density & 5.53 & 1.44 & & & 0.63 \\
\hline Height of cut & 5.31 & 1.44 & & & 0.54 \\
\hline Mowing frequency requirement & 5.64 & 1.49 & & 0.49 & \\
\hline Water requirement & 5.76 & 1.55 & & 0.68 & \\
\hline Fertilizer requirement & 5.35 & 1.55 & & 0.85 & \\
\hline $\begin{array}{l}\text { Pesticide requirement (e.g., weed, insect, } \\
\text { or disease control) }\end{array}$ & 5.31 & 1.63 & & 0.76 & \\
\hline Origin (U.S. native vs. nonnative) & 4.48 & 1.79 & 0.54 & & \\
\hline Speed of germination & 5.19 & 1.51 & 0.55 & & \\
\hline Price & 5.88 & 1.46 & & & \\
\hline Ability to withstand foot traffic & 5.49 & 1.63 & 0.57 & & \\
\hline Appearance & 5.73 & 1.44 & & & 0.60 \\
\hline Winter tolerance & 5.50 & 1.62 & 0.58 & & \\
\hline Disease tolerance & 5.81 & 1.45 & 0.56 & & \\
\hline Grow well in both sun and shade areas & 5.95 & 1.43 & 0.60 & & \\
\hline Weed resistance & 5.98 & 1.40 & 0.50 & & \\
\hline Environmentally friendly & 5.51 & 1.59 & 0.61 & & \\
\hline Seed shelf life & 4.90 & 1.60 & 0.69 & & \\
\hline Eigenvalue & & & 8.61 & 0.71 & 0.63 \\
\hline$\%$ of total variance & & & 79.12 & 6.52 & 5.75 \\
\hline Total variance & & & & & 91.39 \\
\hline
\end{tabular}

converting home lawns to low-input turfgrasses would be relatively challenging (row 4); low-input turfgrasses are not offered in the market and there is insufficient information about them (row 9-10). We reversed the ratings for negative statements (row 4, 9, and 10) when calculating each participant's average rating to measure their willingness to adopt low-input turfgrasses.

Results of the linear regression examining participants' willingness to use low-input turfgrasses are shown in Table 5. There were 1452 Willing Adopters in our study, which accounted for $66.18 \%$ of the sample. Participants in this group showed a positive attitude toward the adoption of low-input turfgrasses. Results showed that Willing Adopters who rated maintenance attributes as important were more willing to use low-input turfgrasses. Although peer effect was found to have no impact on Willing Adopters' willingness of adopting low-input turfgrass, when other identified adoption barriers were overcome, participants in this group will be more likely to use low-input turfgrass. The coefficients of these factors are positive and significant at $1 \%$ significant level.

There were 742 Reluctant Homeowners, which accounted for $33.82 \%$ of the sample. Participants in this group showed reluctance to adopt low-input turfgrasses. For Reluctant Homeowners, the estimated coefficients for importance of maintenance attributes, importance of appearance attributes, and four of five adoption barriers were statistically significant, with the exception being the barrier of benefits and accessibility. Notably, for this group, the coefficient for the importance of appearance attribute is negative and significant at the $1 \%$ level; this means that the more important appearance attributes are to Reluctant Homeowners, the less likely they are to adopt low-

Table 3. Exploratory factor analysis for adoption barriers of low-input turfgrasses based on turfgrass adoption barrier survey $(\mathrm{N}=2194){ }^{\mathrm{z}}$

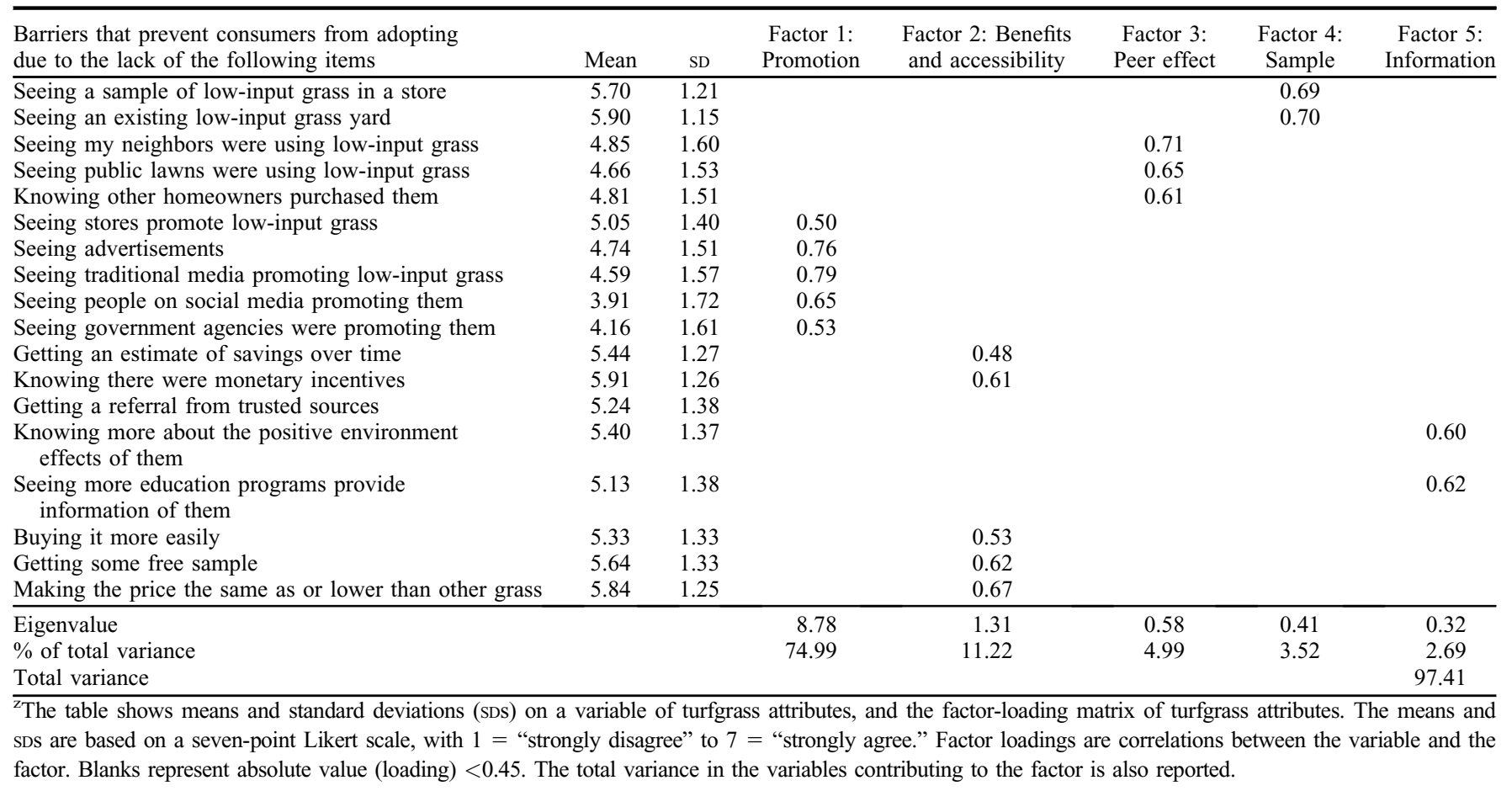


Table 4. Measurement of consumers' willingness to adopt low-input turfgrasses based on turfgrass adoption barrier survey.

How much do you agree with the following statements:

I am willing to replace my lawn with low-input grass.

I am willing to completely redo my lawn and switch to low-input grass.

I am willing to buy low-input grass seed from now on and gradually switch to low-input grass.

Converting my current grass to low-input grass requires too much effort

I believe low-input grasses would save money in the long run.

Generally using low-input grasses on home lawns has more advantages than disadvantages.

I would support municipal programs to help homeowners convert residential lawns to low-input grasses.

I would support my city converting public lawns to low-input grass. It is difficult for me to buy low-input grass because they are not available in

There was not much information regarding low-input turfgrass as far as I know.

${ }^{2}$ Means and standard deviations (SDS) are based on a seven-point Likert scale, with agree" to $7=$ "strongly agree." We reversed the ratings for negative statements (row 4, 9, and 10 ) when calculating each participant's average rating in Table 5 .

input turfgrasses. People in this group might think low-input turfgrasses are not as aesthetically appealing as conventional turfgrass species. These results suggest that emphasizing the maintenance attributes and eliminating the identified barriers would significantly alleviate reluctance to the adoption of low-input turfgrass.

Social-demographic backgrounds for different groups of participants. We used the Student's $t$ test to examine whether there were significant differences in sociodemographic backgrounds between the two (Table 6). Although most participants come from the southern United States, the percentage of
Willing Adopters who lived in western areas was significantly greater than the percentage of Reluctant Homeowners, which may be due to the water scarcity and higher water price in the western U.S. areas. Moreover, compared with the Reluctant Homeowners, Willing Adopters were younger, more likely to have children younger than 12 and pets, had a larger household, and higher household income (better socioeconomic status). Willing Adopters also maintained their lawn more frequently and had a more strict standard for low-input maintenance requirements. However, the two groups have no significant differences regarding gender, education level,

Table 5. Factors influencing consumers' willingness to switch to low-input turfgrasses based on turfgrass adoption barrier survey. ${ }^{\mathrm{z}}$

\begin{tabular}{lcc}
\hline Dependent: standardized willingness score & Willing adopters & Reluctant homeowners \\
\hline Panel A: Important attributes & & \\
Importance of performance attributes & 0.025 & 0.025 \\
& $(0.032)$ & $(0.034)$ \\
Importance of maintenance attributes & $0.112^{* * *}$ & $0.102^{* * *}$ \\
& $(0.030)$ & $(0.031)$ \\
Importance of appearance attributes & -0.035 & $-0.143^{* * *}$ \\
& $(0.031)$ & $(0.037)$ \\
Panel B: Adoption barriers & & $0.107^{* * *}$ \\
Promotion & $(0.022)$ & $0.112^{* * *}$ \\
& $0.189^{* * *}$ & $(0.024)$ \\
Benefits and accessibility & $(0.027)$ & 0.043 \\
& 0.019 & $(0.026)$ \\
Peer effect & $(0.024)$ & $0.135^{* * *}$ \\
& $0.209^{* * *}$ & $(0.027)$ \\
Sample & $(0.027)$ & $0.063^{* *}$ \\
& $0.190^{* * *}$ & $(0.026)$ \\
Information & $(0.028)$ & $0.113^{* * *}$ \\
& $0.419^{* * *}$ & $(0.029)$ \\
Constant & $(0.017)$ & $-0.918^{* * *}$ \\
$R^{2 y}$ & 0.19 & $(0.021)$ \\
No. of observations & 1452 & 0.17 \\
\hline
\end{tabular}

${ }^{\mathrm{z}}$ Statistics show coefficients and robust standard errors (in parentheses) from our linear regression models, where the dependent variable is the standardized score of willingness to adopt low-input turfgrasses. $*, * *, * * *$ indicate significance at $10 \%, 5 \%$, and $1 \%$, respectively.

${ }^{\mathrm{y}}$ The R-squared values are relatively low, but we are confident that our models and results are valid. Rsquared values are typically low in social and behavioral studies because there is an inherently great amount of unexplainable variations. But we can still draw important conclusions about the relationships between variables as the independent variables are statistically significant. Statistically significant coefficients continue to represent the mean change in the dependent variable given a one-unit shift in the independent variable (Grace-Martin, 2012; Neter et al., 1996). In addition, there are many studies in the social science literature that have low R-squares values (e.g., Carley et al., 2019; Slater and Narver, 2000). expected years to live in current residency, and yard size.

Information sources of lawn care. Participants' information sources for lawn care and how trustworthy they think of each information source are presented in Table 7. Overall, participants trusted in a number of information sources. Large gardening centers and local gardening stores were ranked as the most trustworthy sources of information for both Willing Adopters and Reluctant Homeowners; these were followed by University Extension, family and friends, lawn care companies, and large home centers and retailers. In addition, by conducting the Student's $t$ test, the $P$ value suggested that Reluctant Homeowners showed significantly lower levels of trust in all information sources than their Willing Adopter counterparts.

\section{Discussion}

We sought to investigate the factors that influence the consumer's willingness to adopt low-input turfgrasses and proposed viable approaches to improve the adoption rate. Using results from an online survey, we identified the importance of different turfgrass attributes to consumers and different barriers to adopting low-input turfgrass, and then examined how the importance of attributes and barriers affect consumers' willingness to adopt low-input turfgrasses for two consumer segments: Willing Adopters and Reluctant Homeowners. In addition, we learned which sources of lawn care information were most trusted by consumers.

Valuing maintenance attributes was positively associated with willingness to use lowinput turfgrass for all consumers, which is consistent with the finding of other studies in the United States and Canada (Hugie et al., 2012; Yue et al., 2012). This is not surprising, as lowinput turfgrass requires less watering, less fertilizing, fewer pesticide applications, and less mowing (Barnes et al., 2020; Bonos and Huff, 2013; Braun et al., 2020; Cisar, 2010; Watkins et al., 2011, 2014). Reluctant Homeowners, who regard appearance attributes as more important, were more reluctant to adopt lowinput turfgrasses. Yue et al. (2017a) found that more than one-third of both U.S. and Canadian consumers were considered appearance-conscious consumers. Taken together, this suggests that many consumers might perceive the appearance of the low-input turfgrasses as less desirable than that of conventional species. Under low- to medium-maintenance cool-season lawn care management regimens, the difference in aesthetics between lower-input species, such as the fine fescues, and conventional options, like kentucky bluegrass, is not a concern (Hugie and Watkins, 2016); however, turfgrass breeders should continue to keep in mind that a significant number of consumers demand turfgrasses that are both functional and aesthetically pleasing.

Although consumer willingness to adopt low-input turfgrasses is positively associated with how highly a consumer ranks maintenance attributes, this willingness does not always consistently translate into an adoption 


\begin{tabular}{|c|c|c|c|c|c|c|}
\hline \multirow[b]{2}{*}{ Characteristics } & \multirow[b]{2}{*}{ Descriptions } & \multicolumn{2}{|c|}{ Willing adopters } & \multicolumn{2}{|c|}{ Reluctant homeowners } & \multirow[b]{2}{*}{$P$ value } \\
\hline & & Mean & SD & Mean & SD & \\
\hline \multirow[t]{4}{*}{ Region } & Northeast, $1=$ Yes; $0=$ No & 0.16 & 0.01 & 0.18 & 0.01 & 0.20 \\
\hline & Midwest, $1=$ Yes; $0=$ No & 0.24 & 0.01 & 0.27 & 0.02 & 0.20 \\
\hline & South, $1=$ Yes; $0=$ No & 0.43 & 0.01 & 0.42 & 0.02 & 0.79 \\
\hline & West, $1=$ Yes; $0=$ No & 0.17 & 0.01 & 0.13 & 0.01 & $<0.01$ \\
\hline Age & $\begin{array}{l}1=18-25 ; 2=26-35 ; 3=36-45 ; 4=46-55 ; 5=56-65 \\
\quad 6=65+\end{array}$ & 4.53 & 1.35 & 4.64 & 1.42 & 0.07 \\
\hline Gender & $1=$ female $0=$ male & 0.80 & 0.40 & 0.82 & 0.38 & 0.15 \\
\hline Education & $\begin{array}{l}1=\text { some high school or less; } 2=\text { high school diploma; } \\
3=\text { some college; } 4=\text { college diploma; } 5=\text { some } \\
\text { graduate school; } 6=\text { graduate degree and above }\end{array}$ & 4.14 & 1.56 & 4.08 & 1.52 & 0.39 \\
\hline Children younger than 12 & $1=$ yes; $0=$ no & 0.19 & 0.40 & 0.14 & 0.35 & $<0.01$ \\
\hline Pets play on lawn & $1=$ yes; $0=$ no & 0.60 & 0.49 & 0.54 & 0.50 & $<0.01$ \\
\hline Household size & $\begin{array}{l}\text { Number of people in the household }(1-8) \text {, where } \\
\text { " } 8 \text { " represents there are more than } 8 \text { people in the } \\
\text { household }\end{array}$ & 2.55 & 1.32 & 2.33 & 1.29 & $<0.01$ \\
\hline Household income & $\begin{aligned} 1= & \$ 15,000 \text { or less; } 2=\$ 15,001-\$ 25,000 \\
3 & =\$ 25,001-\$ 35,000 ; 4=\$ 35,001-\$ 50,000 \\
5 & =\$ 50,001-\$ 65,000 ; 6=\$ 65,001-\$ 80,000 \\
7 & =\$ 80,001-\$ 100,000 ; 8=\$ 100,001-\$ 150,000 \\
9 & =\$ 150,001-\$ 200,000 ; 10=\$ 200,001 \text { and over }\end{aligned}$ & 5.07 & 2.42 & 4.51 & 2.34 & $<0.01$ \\
\hline $\begin{array}{l}\text { Expected years lives in current } \\
\text { residence }\end{array}$ & $\begin{array}{l}1=1-3 \text { years; } 2=4-6 \text { years; } 3=7-9 \text { years; } 4=10-12 \\
\text { years; } 5=13-15 \text { years; } 6=15+\text { years }\end{array}$ & 4.25 & 1.93 & 4.29 & 1.98 & 0.71 \\
\hline Yard size & $\begin{array}{l}1=\text { less than } 1 / 8 \text { acre; } 2=\text { city lot }(1 / 8 \text { acre }) ; 3=1 / 4 \text { acre; } \\
\quad 4=1 / 2 \text { acre; } 5=1 \text { acre; } 6=\text { More than } 1 \text { acre }\end{array}$ & 3.16 & 1.64 & 3.23 & 1.69 & 0.40 \\
\hline Frequency maintain your lawn & $\begin{array}{l}1=\text { does not maintain lawn by themselves; } 2=\text { less } \\
\text { frequency than every } 3 \text { months; } 3=\text { every } 3 \text { months; } \\
4=\text { every } 2 \text { months; } 5=\text { monthly; } 6=\text { biweekly; } \\
7=\text { weekly; } 8=\text { more often than weekly }\end{array}$ & 3.96 & 2.47 & 3.78 & 2.53 & 0.10 \\
\hline $\begin{array}{l}\text { Opinion on low-input } \\
\text { maintenance standard }\end{array}$ & $\begin{array}{l}1=\text { weekly or more frequency; } 2=\text { biweekly; } 3=\text { monthly; } \\
4=\text { every } 2 \text { months; } 5=\text { every } 3 \text { months; } 6=\text { every } \\
4 \text { months; } 7=\text { every } 5 \text { months }\end{array}$ & 3.09 & 1.54 & 3.27 & 1.89 & 0.02 \\
\hline $\mathrm{N}$ & & 1452 & & 742 & & \\
\hline
\end{tabular}

${ }^{\mathrm{z}}$ The table shows the means and standard deviations (SDs) of participants' characteristics for Willing Adopters and Reluctant Homeowners. $P$ values from the Student's $t$ test are also reported. $P<0.1, P<0.05, P<0.01$ indicate significance at $10 \%, 5 \%$, and $1 \%$, respectively.

behavior. Consumers face adoption barriers due to the lack of a range of factors: 1) Promotion, 2) Benefits and Accessibility, 3) Peer Effect, 4) Sample, and 5) Information. It is clear that low-input turfgrasses are not promoted effectively to the general consumer, and there are few opportunities for consumers to gain knowledge about these lower-input options. Furthermore, there are few influencers to affect low-input turfgrass adoption.
Consumers will be more willing to adopt low-input turfgrass when appropriate marketing/educational strategies can be put into practice. First, providing information about benefits and knowledge of low-input turfgrasses would improve both Willing Adopters and Reluctant Homeowners' willingness to adopt. Because consumers might not have knowledge of lowinput turfgrass watering and fertilizer requirements, and the resultant environmental benefits,

Table 7. Comparison of information sources for Willing Adopters and Reluctant Homeowners based on turfgrass adoption barrier survey. ${ }^{\mathrm{z}}$

\begin{tabular}{|c|c|c|c|c|c|}
\hline \multirow{2}{*}{$\begin{array}{l}\text { "How trustworthy do you think } \\
\text { the following sources of information } \\
\text { are regarding lawn care?" }\end{array}$} & \multicolumn{2}{|c|}{ Willing adopters } & \multicolumn{2}{|c|}{ Reluctant homeowners } & \multirow[b]{2}{*}{$P$ value } \\
\hline & Mean & SD & Mean & SD & \\
\hline My family & 3.66 & 1.07 & 3.48 & 1.14 & $<0.01$ \\
\hline My friends & 3.42 & 1.00 & 3.26 & 1.04 & $<0.01$ \\
\hline My neighbors & 3.21 & 0.98 & 3.02 & 1.00 & $<0.01$ \\
\hline Lawn care company & 3.48 & 1.00 & 3.25 & 1.00 & $<0.01$ \\
\hline Large home centers and retailers & 3.45 & 0.90 & 3.18 & 0.94 & $<0.01$ \\
\hline $\begin{array}{l}\text { Large gardening centers or local } \\
\text { gardening stores }\end{array}$ & 3.84 & 0.86 & 3.61 & 0.88 & $<0.01$ \\
\hline University Extension & 3.75 & 1.02 & 3.38 & 1.05 & $<0.01$ \\
\hline Government agencies & 3.03 & 1.06 & 2.64 & 1.07 & $<0.01$ \\
\hline Related nonprofit organization & 3.31 & 1.00 & 2.93 & 0.99 & $<0.01$ \\
\hline $\begin{array}{l}\text { Traditional media (including newspaper, } \\
\text { radio, TV, etc.) }\end{array}$ & 2.77 & 0.96 & 2.41 & 0.95 & $<0.01$ \\
\hline Social media & 2.36 & 1.00 & 2.07 & 1.00 & $<0.01$ \\
\hline $\mathrm{N}$ & 1452 & & 742 & & \\
\hline
\end{tabular}

${ }^{\mathrm{z}}$ The table shows the means and standard deviations (SDS) of participants' rating of trustworthy information sources for Willing Adopters and Reluctant Homeowners. Means and SDS are based on a five-point Likert scale, with $1=$ "not trustworthy at all" to $5=$ "extremely trustworthy." $P$ values from the Student's $t$ test are also reported. $P<0.1, P<0.05, P<0.01$ indicate significant at $10 \%, 5 \%$, and $1 \%$, respectively.

providing information in these areas would improve their perceived value on low-input turfgrass, and thus willingness to adopt. This is supported by the existing literature on a variety of products that show consumers prefer environmentally friendly products (Helfand et al., 2006; Yue et al., 2010). The Cooperative Extension Service, located at land-grant universities, was designed to educate the communities and can be helpful to convey the proper information and knowledge about the low-input turfgrasses as well as their benefits and advantages. The trustworthiness ranking of university sources in the present study confirms earlier findings by Yue et al. (2017b) that consumers ranked University Extension as second only to family members in terms of trustworthiness for lawn care information; however, participants in that study rank family members, garden centers, and lawn care centers as more useful sources of information than University Extension on lawn care. Overall, these findings point to the need for Extension programs to direct outreach and education efforts toward important information sources such as retail centers.

Similarly, promoting low-input turfgrasses would also raise consumers' awareness of the low-input turfgrass species, and would therefore effectively increase their willingness to adopt low-input turfgrass. This is true for both Willing Adopters and Reluctant Homeowners. Given the low public awareness of these grasses, combined with high levels of trustworthiness for retail outlets, sellers of turfgrasses 
could expand the market substantially by promotion through stores/traditional media/social media/government agencies. Using content developed from University Extension programs can provide important information for consumers, especially those who have concerns about the higher input needs of conventional turfgrasses, but are unaware of lowerinput options or how to convert their lawn to a new turfgrass.

Furthermore, our results show consumers who regard appearance attributes as important are more reluctant to adopt the low-input turfgrass, which might be because consumers are unaware or not confident about the appearance attributes of low-input grasses. Providing photos or exhibiting in-store samples of low-input turfgrass could help eliminate the negative impression and attract both Reluctant Homeowners and Willing Adopters. Large gardening centers, local gardening stores, large home centers, and retailers can be appropriate places to exhibit grass samples, as those places were rated among the top most trustworthy sources of information for lawn care. More importantly, as previous research suggested, product display could significantly impact consumers' purchasing decisions. For example, Bushong et al. (2010) conducted a laboratory experiment to study whether the form in which items are displayed at the time of decision affects participants' willingness to pay; they found willingness to pay is $40 \%$ to $61 \%$ higher for products with the actual item displayed than those with image and text displays.

Peer effect is how the behavior of others influences consumers' likelihood to buy and use a product. In the present study, peer effect is characterized as neighbors/public lawns/ other households that were using low-input turfgrass. Although peer effect had no significant effect on increasing willingness to adopt low-input turfgrass for Willing Adopters, seeing peers use low-input turfgrass would affect Reluctant Homeowners' adoption. This suggests that peer effect can effectively boost Reluctant Homeowners' interest in low-input turfgrass. It has been shown that peer effect snowballs over time when the first peer impacts the second, the second peer impacts with the third, and so on (Dahl et al., 2014). Peer effect can lead to higher long-term adoption rate. Triggering communication between different types of consumers on the benefits of low-input turfgrass on social network can generate positive word of mouth and would be an effective way of promoting it.

Last, providing incentives and improving accessibility to low-input turfgrass would also serve as an effective way to increase consumers' willingness to adopt, especially for Willing Adopters. Providing incentives such as giving free samples of seed, providing monetary incentives to use low-input turfgrasses, and contrasting establishment and maintenance costs of traditional and low-input turfgrasses, as well as improving accessibility can help retailers attract Willing Adopters.

\section{Conclusions}

Using data from an online survey, this article provides empirical evidence on the factors that influence the consumer's willingness to adopt low-input turfgrasses and aim to propose viable ways that could increase the adoption rate. We segmented participants into two groups based on their attitudes toward the adoption of low-input turfgrasses. For Willing Adopters who showed a positive attitude toward the adoption of low-input turfgrasses, the importance of maintenance attributes is positively associated with the willingness, and the results suggest that marketing strategies, such as promoting, providing incentive and improving accessibility, exhibiting samples, and providing benefits information on lowinput turfgrasses would effectively improve their adoption. For Reluctant Homeowners, although the importance of maintenance attributes is positively associated with their willingness to adopt, the more they care about the appearance of the turfgrass, the more reluctant they are to use these grasses. Nevertheless, we find potential strategies to improve Willing Adopters' willingness to adopt could also be applied to Reluctant Homeowners.

This study addressed the increasing interest in the adoption of an environmentally friendly product: low-input turfgrasses. Our study differs from existing studies in that it examined a comprehensive list of factors that could influence consumers' adoption decisions, including the important attributes, adoption barriers, sociodemographic characteristics, and trustworthiness of various sources of lawn care information, with an emphasis on adoption barriers of low-input turfgrass and ways to overcome them. Although there are plenty of studies providing empirical support for consumer preference for low-turfgrasses attributes, few have explored the barriers that prevent consumers from adopting low-input turfgrasses. This study investigated both the role of turfgrass attribute importance and adoption barriers in shaping turfgrass consumers' decision-making to access the key demographics of the low-input turfgrass markets.

Our study has some limitations that should be addressed in future research. As our survey was limited to homeowners, we are not clear about the barriers other types of consumers are facing when converting to low-input species, such as public land managers, athletic field managers, architects, landscape designers, or decision-making residents who rent homes with lawns. In addition, there might be other factors and strategies that would possibly improve the adoption rates of the low-input turfgrass, such as governmental support for resident conversion to low-input turfgrass through policy and incentive programs. Future research should examine the role that government policy and programs could play in the adoption process.

\section{Literature Cited}

Barnes, M.R., K.C. Nelson, A.R. Kowalewski, A.J. Patton, and E. Watkins. 2020. Public land manager discourses on barriers and opportunities for a transition to low input turfgrass in urban areas. Urban For. Urban Green. 53:126745, doi: 10.1016/j.ufug.2020.126745.

Barnes, M.R., K.C. Nelson, A.J. Meyer, E. Watkins, S.A. Bonos, B.P. Horgan, W.A. Meyer, J. Murphy, and C. Yue. 2018. Public land managers and sustainable urban vegetation: The case of low-input turfgrasses. Urban For. Urban Green. 29:284-292, doi: 10.1016/j.ufug.2017.12.008.

Beard, J.B. and R.L. Green. 1994. The role of turfgrasses in environmental protection and their benefits to humans. J. Environ. Qual. 23(3):452-460, doi: 10.2134/jeq1994.00472425002300030007x.

Bonos, S.A. and D.R. Huff. 2013. Cool-season grasses: Biology and breeding, p. 591-660. In: J.C. Stier, B.P. Horgan, and S.A. Bonos (eds.). Turfgrass: Biology, use, and management, Vol. 56, John Wiley \& Sons, Hoboken, NJ, doi: 10.2134/agronmonogr56.c17.

Braun, R.C., A.J. Patton, E. Watkins, P.L. Koch, N.P. Anderson, S.A. Bonos, and L.A. Brilman. 2020. Fine fescues: A review of the species, their improvement, production, establishment, and management. Crop Sci. 60(3):1142-1187, doi: $10.1002 / \csc 2.20122$.

Burgin, S. 2016. What about biodiversity? Redefining urban sustainable management to incorporate endemic fauna with particular reference to Australia. Urban Ecosyst. 19(2):669-678, doi: 10.1007/s11252-015-0522-0.

Bushong, B., L.M. King, C.F. Camerer, and A. Rangel. 2010. Pavlovian processes in consumer choice: The physical presence of a good increases willingness-to-pay. Amer. Econ. Rev. 100(4):1556-1571, doi: 10.1257/aer.100.4.1556.

Carley, S., S. Siddiki, and S. Nicholson-Crotty. 2019. Evolution of plug-in electric vehicle demand: Assessing consumer perceptions and intent to purchase over time. Transp. Res. Part D Transp. Environ. 70:94-111.

Cisar, J.L. 2010. Reducing environmental impacts of fertilizers and pesticides through sustainable high performance turfgrass systems. In XXVIII International Horticultural Congress on Science and Horticulture for People (IHC2010): International Symposium. Acta Hort. 938:105-111, doi: 10.17660/ActaHortic.2012.938.13.

Cohen, S., A. Svrjcek, T. Durborow, and N.L. Barnes. 1999. Water quality impacts by golf courses. J. Environ. Qual. 28(3):798-809, doi: 10.2134/jeq1999.00472425002800030010x.

Dahl, G.B., K.V. Løken, and M. Mogstad. 2014. Peer effects in program participation. Amer. Econ. Rev. 104(7):2049-2074, doi: 10.3386/ w18198.

Demuzere, M., K. Orru, O. Heidrich, E. Olazabal, D. Geneletti, H. Orru, A.G. Bhave, N. Mittal, E. Feliu, and M. Faehnle. 2014. Mitigating and adapting to climate change: Multi-functional and multi-scale assessment of green urban infrastructure. J. Environ. Mgt. 146:107-115, doi: 10.1016/ j.jenvman.2014.07.025.

Easton, Z.M. and A.M. Petrovic. 2004. Fertilizer source effect on ground and surface water quality in drainage from turfgrass. J. Environ. Qual. 33(2):645-655, doi: 10.2134/jeq2004.0645.

Fabrigar, L.R., D.T. Wegener, R.C. MacCallum, and E.J. Strahan. 1999. Evaluating the use of exploratory factor analysis in psychological research. Psychol. Methods 4(3):272-299, doi: 10.1037/1082-989x.4.3.272.

Fry, J. and B. Huang. 2004. Applied turfgrass science and physiology. John Wiley \& Sons, Hoboken, NJ

Fu, J.M., J. Fry, and B.R. Huang. 2004. Minimum water requirements of four turfgrass in the transition zone. HortScience 39(7):1740-1744, doi: 10.21273/HORTSCI.39.7.1740 
Ghimire, M., T.A. Boyer, and C. Chung. 2019. Heterogeneity in urban consumer preferences for turfgrass attributes. Urban For. Urban Green. 38:183-192, doi: 10.1016/j.ufug.2018.12.003.

Gilliom, R.J., J.E. Barbash, C.G. Crawford, P.A. Hamilton, J.D. Martin, N. Nakagaki, L.H. Nowell, J.C. Scott, P.E. Stackelberg, G.P. Thelin, and D.M. Wolock. 2006. Pesticides in the nation's streams and ground water, 19922001 (No. 1291). US Geological Survey, doi: $10.3133 / \operatorname{cir} 1291$.

Grace-Martin, K. 2012. Can a regression model with a small R-squared be useful? The Analysis Factor. <https://www.theanalysisfactor.com/ small-r-squared/ $>$.

Heiner, R.A. 1985. Origin of predictable behavior: Further modeling and applications. Amer. Econ. Rev. 75(2):391-396. <https://www.jstor. org/stable/1805631>.

Helfand, G.E., J.S. Park, J.I. Nassauer, and S. Kosek. 2006. The economics of native plants in residential landscape designs. Landsc. Urban Plan. 78(3):229-240, doi: 10.1016/j.landurbplan.2005. 08.001 .

Henry, J.M., S.N. Wegulo, V.A. Gibeault, and R. Autio. 2005. Turfgrass performance with reduced irrigation and nitrogen fertilization. Intl. Turfgrass Soc. Res. J. 10:93-101.

Huang, B. and J. Fu. 2000. Photosynthesis, respiration, and carbon allocation of two cool-season perennial grasses in response to surface soil drying. Plant Soil 227(1):17-26, doi: 10.1023/ a: 1026512212113.

Hugie, K., C. Yue, and E. Watkins. 2012. Consumer preferences for low-input turfgrasses: A conjoint analysis. HortScience 47(8):1096-1101, doi: 10.21273/hortsci.47.8.1096.

Hugie, K.L. and E. Watkins. 2016. Performance of low-input turfgrass species as affected by mowing and nitrogen fertilization in Minnesota. HortScience 51(10):1278-1286, doi: 10.21273/ hortsci11007-16.

Ignatieva, M., D. Haase, D. Dushkova, and A. Haase. 2020. Lawns in cities: From a globalised urban green space phenomenon to sustainable nature-based solutions. Land (Basel) 9(3):73, doi: 10.3390/land9030073.

Jenkins, V. 2015. The lawn: A history of an American obsession. Smithsonian Institution.

Law, Q.D. and A.J. Patton. 2017. Biogeochemical cycling of carbon and nitrogen in cool-season turfgrass systems. Urban For. Urban Green. 26:158-162, doi: 10.1016/j.ufug.2017.06.001.

Lee, S. and L. McCann. 2018. Passage of phosphorus-free lawn fertilizer laws by US States. J. Nat. Resour. Policy Res. 8(1-2):66-88. https://www.jstor.org/stable/10.5325/naturesopo lirese.8.1-2.0066.
Maupin, M.A., J.F. Kenny, S.S. Hutson, J.K. Lovelace, N.L. Barber, and K.S. Linsey. 2014. Estimated use of water in the United States in 2010 (No. 1405). US Geological Survey, doi: 10.3133/cir1405.

Mayer, P.W., W.B. DeOreo, E.M. Opitz, J.C. Kiefer, W.Y. Davis, B. Dziegielewski, and J.O. Nelson. 1999. Residential end uses of water. AWWA Research Foundation and American Water Works Association.

Milesi, C., C.D. Elvidge, J.B. Dietz, B.T. Tuttle, R.R. Nemani, and S.W. Running. 2005. A strategy for mapping and modeling the ecological effects of US lawns. J. Turfgrass Manage. 1(1):83-97.

Milman, A. and C. Polsky. 2016. Policy frameworks influencing outdoor water-use restrictions. J. Amer. Water Resour. Assoc. 52(3):605-619, doi: 10.1111/1752-1688.12409.

Monteiro, J.A. 2017. Ecosystem services from turfgrass landscapes. Urban For. Urban Green. 26:151-157, doi: 10.1016/j.ufug.2017.04.001.

Neter, J., M.H. Kutner, C.J. Nachtsheim, and W. Wasserman. 1996. Applied linear regression models. 3rd ed. Richard D. Irwin, Inc., Chicago, IL.

Norton, B.A., A.M. Coutts, S.J. Livesley, R.J. Harris, A.M. Hunter, and N.S. Williams. 2015. Planning for cooler cities: A framework to prioritise green infrastructure to mitigate high temperatures in urban landscapes. Landsc. Urban Plan. 134:127-138, doi: 10.1016/j.landurbplan. 2014.10.018.

Qian, Y., R.F. Follett, and J.M. Kimble. 2010. Soil organic carbon input from urban turfgrasses. Soil Sci. Soc. Amer. J. 74(2):366-371, doi: 10.2136/sssaj2009.0075.

Qian, Y.L., J.D. Fry, and W.S. Upham. 1997. Rooting and drought avoidance of warm-season turfgrasses and tall fescue in Kansas. Crop Sci. 37(3):905-910, doi: 10.2135/cropsci1997. 0011183x003700030034x.

Robbins, P. 2012. Lawn people: How grasses, weeds, and chemicals make us who we are. Temple University Press, Philadelphia, PA.

Robbins, P. and T. Birkenholtz. 2003. Turfgrass revolution: Measuring the expansion of the American lawn. Land Use Policy 20(2):181-194, doi: 10.1016/s0264-8377(03)00006-1.

Slater, S.F. and J.C. Narver. 2000. The positive effect of a market orientation on business profitability: A balanced replication. J. Bus. Res. 48(1):69-73.

Soldat, D.J. and A.M. Petrovic. 2008. The fate and transport of phosphorus in turfgrass ecosystems. Crop Sci. 48(6):2051-2065, doi: 10.2135/crop sci2008.03.0134.

Stier, J.C., K. Steinke, E.H. Ervin, F.R. Higginson, and P.E. McMaugh. 2013. Turfgrass benefits and issues, p. 105-145. In: J.C. Stier, B.P. Horgan, and S.A. Bonos (eds.). Turfgrass: Biology, use, and management, Vol. 56, The Alliance of Crop, Soil, and Environmental Science Societies (ACSESS), Madison, WI, doi: 10.2134/agronmonogr56.c3.

Street, G., R. James, and H. Cutt. 2007. The relationship between organised physical recreation and mental health. Health Promot. J. Austral. 18(3):236-239, doi: 10.1071/he07236.

$\mathrm{Su}$, K., D.J. Bremer, S.J. Keeley, and J.D. Fry. 2008. Rooting characteristics and canopy responses to drought of turfgrasses including hybrid bluegrasses. Agron. J. 100(4):949-956, doi: 10.2134/agronj2007.0292.

U.S. Drought Monitor. 2020. Nov. 2020. <https:// droughtmonitor.unl.edu $>$.

U.S. Environmental Protection Agency. 2020. Nov. 2020. <https://www.epa.gov/agriculture/ laws-and-regulations-apply-your-agriculturaloperation-farm-activity $>$.

Watkins, E., S. Fei, D. Gardner, J. Stier, S. Bughrara, D. Li, C. Bigelow, L. Schleicher, B. Horgan, and K. Diesburg. 2011. Low-input turfgrass species for the north central United States. Appl. Turfgrass Sci. 8(1):1-11, doi: 10.1094/ats-2011-012602-rs.

Watkins, E., D.S. Gardner, J.C. Stier, D.J. Soldat, R.A. St. John, N.E. Christians, A.D. Hathaway, K.L. Diesburg, S.R. Poppe, and R.E. Gaussoin. 2014. Cultivar performance of low-input turfgrass species for the north central United States. Appl. Turfgrass Sci. 11(1):1-7, doi: 10.2134/ats-2013-0101-rs.

Yue, C., C.R. Hall, B.K. Behe, B.L. Campbell, J.H. Dennis, and R.G. Lopez. 2010. Are consumers willing to pay more for biodegradable containers than for plastic ones? Evidence from hypothetical conjoint analysis and nonhypothetical experimental auctions. J. Agr. Appl. Econ. 42(4): 757-772, doi: 10.1017/s1074070800003941.

Yue, C., K. Hugie, and E. Watkins. 2012. Are consumers willing to pay more for low-input turfgrasses on residential lawns? Evidence from choice experiments. J. Agr. Appl. Econ. 44(4): 549-560, doi: 10.1017/s107407080002410x.

Yue, C., J. Wang, E. Watkins, S.A. Bonos, K.C. Nelson, J.A. Murphy, W.A. Meyer and B.P. Horgan. 2017a. Heterogeneous consumer preferences for turfgrass attributes in the United States and Canada. Can. J. Agr. Econ. 65(3):347-383, doi: 10.1111/cjag.12128.

Yue, C., J. Wang, E. Watkins, S. Bonos, K. Nelson, J.A. Murphy, W. Meyer, and B. Horgan. 2017b. Consumer preferences for information sources of turfgrass products and lawn care. Agron. J. 109(4):1726-1733, doi: 10.2134/agronj2016.05. 0310 . 